\title{
Exploring the Differences Between British and American Englishtowards Better Performance of the English Teacher and the Taught
}

\author{
Muhammad Khan Ph. D. \\ Assistant Prof. \\ College of Arts \& Humanities \\ English Department \\ Jazan University \\ Jazan, Saudi Arabia
}

\begin{abstract}
The familiarity with the differences between BrE and AmEvocabulary, spelling,pronunciation and grammar is the demand of the day to avoid misunderstanding and confusion in certain situations. The knowledge of thevariations helpsthe English users at all levels to comprehend and communicate in the target language more effectively.Particularly, the EFL teachers need to know the differences between British and American English words and theirpronunciation to answer students' questions like; how can the word 'amateur' be pronounced: The possible answer may be such as - (i) /'cematar/ (ii) /,cema't3:r/ (BrE) whereas AmE (i) /'cematfar/ (ii) /'cematjoar/.Similarly, some confusion related to grammar can also be interrogated. For example, the use of the present perfect differs in BrE and AmE. When referring to an action which has begun in the past, but is going on in the present, the speakers of British English use the present perfect, while Americans dialect tends to use the past simple tense. For example: $(B r E)$ 'John has already finished his work.' but in AmE, 'John already finished his work.' The present study is descriptive one that is based on the data collected through reliable sources. Then the most relevant and important information has been analyzed with reference to classroom situation, communication either oral or written at international level where the use of both BrE and AmE is possible. Students learn what a teacher knows hence the knowledgeof the differences between BrE and AmEvocabulary, spelling, accent and grammar is of prime importance for an EFL or ESL teacher and the taught towards their better performance.
\end{abstract}

Keywords: BrE versus AmE, vocabulary, pronunciation, grammar, anxiety, confusion.

\section{Introduction}

The two varieties of English most widely found in print and taught around the world are British and American. It is, therefore, important for teachers to be aware of the major differences between the two, and while lexical differences are the easiest ones to notice, a knowledge of grammatical and phonological differences can be useful not only for teachers to be aware of, but also to be able to deal with if they come up in classroom situation. Accidentally using one instead of the other will not automatically lead to miscommunication. Americans and British can usually communicate with each other without too much difficulty. Differences in pronunciation between American English (AmE) and British English (BrE) can be divided into two - differences in accent and differences in the pronunciation of individual words in the lexicon. In this article, transcriptions use Received Pronunciation (RP) to represent BrE and General American (GAm) to represent AmE.For many loanwords from French where AmE has kept the original French final-syllable stress, BrE stresses an earlier syllable.There are differences between General American and Received Pronunciation for the standard accents in the United States and Britain.Some examples of words that have German origin are - semester (originally meaning a course of six months), seminar (originally meaning a group of students working with a professor).

In 'Divided by a Common Language', Christopher Davies mentions several countries that enriched English in the US. Immigrants from these countries coming to the United States "have contributed many of the words that distinguish American English from British English" (Davies, 2005).Apart from this, French also named objects that were unknown to them with their own French words. These became a part of the American English vocabulary and remain so to this day (American Heritage Dictionary). Weinreich claims that the language also changes due to "contact between speakers of different languages or dialects, rather than by variation internal to a given speech community" (Weinreich, 1953). This is especially true about the English language as a major lingua franca in the world. 
Moreover,in addition to pronunciation, spelling and vocabulary, there are certain grammar differences between British and American English. For example, in American English, collective nouns are considered singular, e.g. 'The band is playing.' On the other hand, collective nouns can be either singular or plural in British English, although the plural form is most often used as 'The band are playing.' One of the most notable differences between American English and British English is their differences of grammar. For example, subject-verb agreement, verbs, verb morphology, use of tenses, verbal auxiliaries, transitivity, complementation, presence or absence of syntactic elements, definite article, phrasal verbs and miscellaneous grammatical variations.British and American English are the same, both are English language. But there are some significant differences between them, such as words, e.g. ('rail' (AmE and'train' BrE)', spelling, e.g. ('colour' BrE and 'color' AmE), pronunciation, e.g. ('past' /pa:st/ BrE and /pæst/ AmE and grammar, e.g. (British English usually uses "Have you any children?" or "Have you got any children?" whilst Americans commonly express the same meaning with "Do you have any children?").Some students know the differences, but most of students have less knowledge about the differences. Sometimes students and other users of English language are confused when they face certain variations in different areas as given ibid.

The differences may be more marked between US and British English but the English or Englishes spoken in Canada, Australia, New Zealand and South Africa, as well as other non-Anglo varieties such as Indian and Singaporean English, all have their own phonetic, lexical and grammatical patterns capable of causing confusion and frustration when misunderstood.A good understanding of the differences between $\mathrm{AmE}$ and $\mathrm{BrE}$ will help the teacher and the student to communicate more effectively. This is true for the spoken as well as the written language (Modiano, 1996). Both teacher and student's exposure to different dialects and accent would prove useful in the business of life in real life-like situations, e.g. sometimes the course books in the universities of Saudi Arabia are a mixture of British and American authors.

\section{Hypothesis}

The vocabulary, spelling, pronunciation and grammatical variations in BrE and AmE often result in anxiety and confusion for the users of English language in oral and written communication at different levels. In some situations these differences lead to misinterpretation and misunderstanding or communication breakdown.

\section{Conceptual Framework}

In 1887 Oscar Wildewrote that 'we have everything in common with America nowadays, except, of course, language' and this is just as true today as British and American English remain two very distinct varieties of the world's lingua franca.Britain was a very powerful country, and like other European countries, it started forming colonies in other parts of the world. That means that they went to other areas, conquered the people living there, and took control of the land.British colonies included what is now Canada and the United States of America, and that's the main reason why people in those countries speak English today.Over the years, most of the British colonies got independence. This allowed the English they spoke to change slowly. At the same time, the way people in Britain spoke English was also changing, but not in the same way as in the colonies("How to Confuse a Foreigner"2016). Somewords have appeared while some went lost. Words have changed in meaning. The grammatical endings of words have been modified, and many such endings went out of use. There have been turns in word-order. Pronunciation modulated drastically.

The Modern English period can be divided into two distinct periods. The period of Early Modern English dates approximately from 1500-1800 and the period of Late Modern English from 1800 to the present. There were two major factors that clearly separated Middle and Modern English. The first was a change in pronunciation, also known as the Great Vowel Shift, during which the vowels in general started shortening. The other factor was instigated by William Caxton's bringing the printing press to England, which led to the publishing of literature for the masses becoming more popular. Literacy became more common, and works in English were more popular than the ones in Latin. This in turn led to the need for standardized English. The London dialect became the standard (Van Gelderen, 2006).

All together these transformations made the English language develop during the centuries. The history of the English language is usually divided into three broad periods which have been defined as Old English, Middle English and Modern English or New English. These periods overlap important socio-political changes: Old English covers from the first Anglo-Saxon settlements in England to about 1100, Middle English from about 1100 to about 1500, and Modern English from about 1500 to the present day (Pauliuc, 2013).During the period of the French reign about 10,000 French words came into English. French, being of Latin origin, imposed a large influence of the Latin language on the development of English. Much of the modern English vocabulary is of Latin origin rather than of Germanic. During this period most grammatical changes came, re-forming English from the synthetic Old English to the analytic English. English lost most of the case endings of nouns, many irregular and strong forms of verbs were simplified, prefixes and suffixes were used more freely and verbs were no longer conjugated. (Crystal,1995). 
It shows that the differences which may cause the most confusion are in the area of pronunciation and vocabulary. We can add that not only are Received Pronunciation and General American very different, but these two standard pronunciations are only a small fraction of dialects found in Britain and the United States. With selected examples of British idioms and their American equivalents we have shown that often when the two dialects use the same words, phrases or idioms, they may be expressing a completely different meaning; and on the other hand, one meaning can be preferred to be expressed by completely different words or phrases.Changes in a language are of various kinds yet those concerning pronunciation have caused the most disagreements. This is strictly related to the important role played by the influence of foreign idioms. Nations with high commercial, political, and cultural prestige tend to influence the others: for centuries, French influenced all other European languages, while today the English language is penetrating in countries all over the world, largely because of the power and prestige of the United States (KaterinaPauliuc, 2013).

According to Mackward, Albert H (1958), the differences will cause real problem of intelligibility, as he says: "The perceptible but minimal differences that distinguished American from English of United Kingdom (British) seem likely to cause any real problem of intelligibility." (Nancy, 1976) says “... the teaching English in twentieth century demands an accurate awareness of differences between British an American English, because of the influence of both varieties throughout the world." British English (BrE) is a kind of English variety which comes from Britain or England, and it is well-known as Received Pronunciation (RP). It denotes the speech of educated people living in London and Southeast of England and of other people elsewhere who speak in this way. While American English (AmE) is the English language of the United States as distinguished from that used elsewhere more narrowly, it pertains to any word or expression that originated from United States. The accent of English which American people almost speak is called General American (GA) but it is not defined precisely. General American is the pronunciation used by the majority of the population of the United States and by most US radio and TV announcers. It is also the model accent used in teaching English in such parts of the world as Central and South America, the Philippines, etc.

The English language developed over hundreds of years. During that time, it was changing a lot. It was adding new words from languages like Latin, French and German, and it was also changing existing English words. The language is still changing today, so what sounds "normal" now may be "weird" in 100 years!(Sitzman, 2019)."I'm from the United States, and I teach English in Costa Rica, so most of the English that my students have heard and learned has been American English. So for students here, British English seems "weird" (bizarre/unusual).But when I lived in Germany, many people there learned British English, so for them American English was "weird." So let's just say this now: every language variety and every dialect can be both weird and normal. It all depends on your perspective. My students often ask me about the differences between American and British English (Sitzman, 2019).

The differences between AmE and BrE in vocabulary, pronunciation, spelling and grammar are crystal clear. The awareness of those kinds of differences is considered really important to avoid the confusion and misunderstanding. Some people consider these dissimilarities to be of minor concern. Nevertheless, the differences between the two varieties are not always as unimportant as we would like to believe (Modiano, 1996). Sometimes even native speakers don't understand other dialects of English 100\%, and that's definitely true.

\section{Delimitation Of The Study}

The present area of the study is so vast and time demanding.Owing to the time constraint, the research has been delimited only to the most specific differences between British English and American English Vocabulary, spelling, pronunciation and grammar.

\section{Research Questions}

This hypothesis led to formation of a few research questions:

(i) What are the vocabulary, spelling, pronunciation and grammar differences in BrE and AmE?

(ii) How do these variations affect intelligibility of BrE and AmE users?

(iii) What are possible solutions to minimize the present state of confusion for better performance?

\section{Objectives}

TheObjectives of the study are to:

(i) explore differences in $\mathrm{BrE}$ and AmEvocabulary, spelling, pronunciation and grammar,

(ii) determine certain solutions to overcome the expected confusion and secondly to use both BrE and AmE varieties with more clarity and confidence. 


\section{Significance of The Study}

The significance of the present study is that it will (i) give the teacher and the taught some idea about the differences between BrE and AmE vocabulary, spelling, pronunciation and grammar and (ii) prepare them to face certain expected problems in listening comprehension, oral or written communication at varying levels and different situations.

\section{Research Methodology}

Descriptive method has been used due to time and financial constraints. The researcher collected relevant and the most specific data related to the present study through reliable sources and especially the existing research in the area.

\section{Data Collection And Its Analysis}

The researcher collected relevant and the most specific data through reliable sources for the validity of the study. The collected data has been displayed in tables 1- 4 for quick view. Each table and its content have been described and discussed in detail and so clearly for the ease of the readers.

Table-1: BrE and AmE vocabulary differences

\begin{tabular}{|l|l|}
\hline BrE & AmE \\
\hline registering of luggage & checking of baggage \\
\hline afraid & afeared \\
\hline bonnet (the front of the car) & hood \\
\hline boot (the back of the car) & trunk \\
\hline biscuit & cookie \\
\hline time-table & schedule \\
\hline train driver & train engineer \\
\hline guard & conductor \\
\hline railway station & railroad depot \\
\hline car & automobile \\
\hline petrol station & gas station \\
\hline creature & critter \\
\hline figure & Figger \\
\hline Get & Git \\
\hline Join & Jine \\
\hline Catch & Ketch \\
\hline Certain & Sartin \\
\hline Vermin & Vermint \\
\hline baggage & luggage \\
\hline lift & Elevator \\
\hline petrol & gasoline \\
\hline cafe & restaurant \\
\hline shop & store \\
\hline underpants & shorts \\
\hline trousers & pants \\
\hline dd/mm/yyy & mm/dd/yyyy \\
\hline autumn & fall \\
\hline aeroplane & Airplane \\
\hline biscuit $~$ & Cookie/cracker \\
\hline chemist & drugstore/pharmacy \\
\hline crisps & chips \\
\hline dustbin & trashcan/garbage can \\
\hline cinema & movie theater \\
\hline film & movie \\
\hline Fizzy drink & Pop/soda \\
\hline flat & Apartment \\
\hline football & Soccer \\
\hline holiday & Vacation \\
\hline jumper & Sweater/sweat shirt \\
\hline & \\
\hline
\end{tabular}




\begin{tabular}{|l|l|}
\hline lorry & Semi truck \\
\hline maths & Math \\
\hline Mobile phone & Cell phone \\
\hline trousers & Pants/slacks \\
\hline pavement & Sidewalk \\
\hline post & Mail \\
\hline pram & Stroller \\
\hline queue & Line \\
\hline To ring & To call \\
\hline rubber & Eraser \\
\hline motorway & superhighway \\
\hline Sweet(s) & Candy \\
\hline Toilet or loo & Bathroom/restroom \\
\hline trainers & Sneakers/tennis shoes \\
\hline underground & Subway \\
\hline Coriander (French) & Cilantro (Spanish) \\
\hline Aubergine (Arabic) & eggplant \\
\hline university & college \\
\hline wardrobe & Closet \\
\hline zed & zee \\
\hline to be kept on tenterhooks (idiom) & to be on pins and needles \\
& (idiom) \\
\hline
\end{tabular}

\section{Description and discussion:}

(i) Many features of the English language in America are of the 17th century English settlers and have been retained as such. For example, old words and phrases that have totally vanished from the British English region are still used in American English. Even it differs from English, it can be understood with a little effort and specifically American objects and these variations are becoming more and more familiar to English day by day.

(ii) The largest divergences between British English and American English are perhaps in vocabulary. Usually the words that are used by Americans pertaining to travel and transport are different from those used by the English men. The Americans use 'travel by rail' instead of 'travel by train'. Instead of 'registering of luggage', they use 'checking of baggage'. The 'luggage van' is referred to as the 'baggage car'. Instead of 'notice board', they have 'bulletin board'. 'Time-table' is known as 'schedule'. The 'driver' of the train is the 'engineer' and the 'guard' is the 'conductor'. A 'railway station' is known as 'a railroad depot'. The 'car' is invariably an 'automobile' and it is taken to a 'gas station' for being supplied with petrol.

(iii) But these differences are not such as cannot be easily removed and are not very formidable to any intelligent traveller. The films and American literature have made people in England quite familiar with the new words and terms of expression in America at the same time.

(iv) There are so many reasons that bear a great impact upon the American English vocabulary. In the USA many features of the language of the 17th century English settlers have been retained as such.

(v) It is a fact that the literary language of the USA and that of Great Britain are more or less the same. At least they have not diverged perceptibly so as to give the feeling that British English and American English are entirely two different things. In spite of all that has been said it has still to be admitted that the American vocabulary is mainly the same as English. Even it differs from English, it can be understood with little effort.

(vi) In many cases, when speaking about American and British equivalents, the distinction is not really a matter of one nation having one word or expression which the other variety is not familiar with and vice versa. It's more a matter of one of the expressions being prevalent and most widely used in one of the varieties.Sometimes, two different words are used but their meaning is quite obvious, such as the American 'luggage' and the British 'baggage' or 'elevator' and 'lift', 'gasoline' and 'petrol'.

(vii) The two types of English have borrowed words from different languages.

(viii) "It's clear that British and American English have evolved differently when you consider the cultural influences that have affected each independently, and how they've borrowed words from those languages. For some reason this is very common with words for food: examples include coriander (British, derived from French) and cilantro (American, derived from Spanish), and aubergine (British, derived from Arabic)" (Kachru, 2006). 
(ix) Here is an interesting experience, "a porter in a British hotel comes upon an American tourist impatiently jabbing at the button for the lift."Sir, the lift will be here in a moment."'Lift? Lift?" replies the American. "Oh, you mean the elevator.""No sir, here we call it a lift.""Well, as it was invented in the United States, it's called an elevator."'Yes sir, but as the language was invented here, it's called a lift"' (The Reader's Digest, 2012).

Table-2: BrE and AmE spelling differences

\begin{tabular}{|c|c|}
\hline BrE & AmE \\
\hline adviser & advisor \\
\hline colour & color \\
\hline dialogue & dialog \\
\hline theatre & theater \\
\hline programme & program \\
\hline -our (colour) & -or (color) \\
\hline -ise (realise) & -ize (realize) \\
\hline traveller & traveler \\
\hline travelled & traveled \\
\hline travelling & traveling \\
\hline waggon & wagon \\
\hline counsellor & Counselor \\
\hline skilful & skillful \\
\hline fulfil & fullfil \\
\hline catalogue & catalog \\
\hline defence & defense \\
\hline plough & plow \\
\hline make-up. & Make up \\
\hline neo-colonialism & neocolonialism \\
\hline aluminium & aluminum \\
\hline Cheque & check \\
\hline Jewellery & jewelry \\
\hline Pyjamas & pajamas \\
\hline Sulphur & sulfur \\
\hline Tyre & tire \\
\hline whisky & whiskey \\
\hline $\begin{array}{l}\text {-oe-/-ae- (e.g. anaemia, diarrhoea, } \\
\text { encyclopaedia) }\end{array}$ & $\begin{array}{l}\text {-e- (e.g. anemia, diarrhea, } \\
\text { encyclopedia) }\end{array}$ \\
\hline -re (e.g. metre, fibre, centre) & -er (e.g. meter, fiber, center) \\
\hline -ence (e.g. defence, offence, licence) & $\begin{array}{lll}\text {-ense (defense, offense, } \\
\text { license) }\end{array}$ \\
\hline -re (e.g. metre, fibre, centre) & -er (e.g. meter, fiber, center) \\
\hline
\end{tabular}

\section{Description and Discussion}

(i) English spellings follow a relatively straight-forward set of phonetic principles. The reputation of English spelling is, however, notoriously bad.This lies in the fact the realization of the principles draws on a large number of traditional spellings which themselves go back to differing conventions of both spelling and pronunciation.

(ii) Above all, English orthography has been relatively resistant toward a spelling reform.Simplification is a principle common to both the British and the American traditions, but is sometimes realized differently.

(iii) AmE avoids hyphenation. BrE writes 'make-up' and AmE'make up' and BrE neo-colonialism, but AmE neocolonialism. But even the limited reforms generally prevailing in American English have not been embraced within the British English spelling tradition.

(iv) The distinctive features of American spelling are mainly the legacy left by Noah Webster(Yazawa, 2004) whose "American Spelling Book" appeared in 1783 and was followed by his "American Dictionary of the English Language" in 1828. Slowly, he changed the spelling of words, such that they became 'Americanized'.

(v) Principles involved in the reformation of spelling are the principles of simplification, regularization, derivational, uniformity, reflection of pronunciation, including stress indication, and spelling pronunciations. 
(vi) Much of the variation lies in the greater willingness on the part of American English users to accept the few modest reforms that have been suggested. Simplification is a principle common to both the British and the American traditions, but is sometimes realized differently.

Table-3: BrE and AmE pronunciation differences

\begin{tabular}{|c|c|c|}
\hline Word & BrE (RP) & AmE (GA) \\
\hline winter & win-tuh & win-terr \\
\hline hard & [ha:d] & [hard] \\
\hline born & [bo:n] & [born] \\
\hline hurt & [hə:t] & ['hərt] \\
\hline later & ['leito] & [leirər] \\
\hline here & [hı。 & [hiər] \\
\hline there & [ðеə] & [ðeər] \\
\hline Car & $\mathrm{k} \alpha$ : & ka:r \\
\hline Near & Niə & nir \\
\hline not & [npt] & [na:t] \\
\hline lot & {$[\mathrm{lnt}]$} & [la:t] \\
\hline hot & {$[\mathrm{hbt}]$} & [ha:t] \\
\hline knowledge & [nplid3] & [na:lidz] \\
\hline dance & [da:ns] & [dæns] \\
\hline past & [pa:st] & [pæst] \\
\hline half & [ha:f] & [hæf] \\
\hline math & {$[\mathrm{ma}: \theta]$} & {$[\mathrm{mæ} \theta]$} \\
\hline aunt & [a:nt] & [ænt] \\
\hline example & [igza:mpsl] & [igzæmpsl] \\
\hline thought & $[\theta\lrcorner: t]$ & {$[\theta \mathrm{a}: \mathrm{t}]$} \\
\hline walk & [wo:k] & [wa:k] \\
\hline daughter & [do:to] & [da:tør] \\
\hline clear & [kliə] & [klir] \\
\hline dare & [deə] & [der] \\
\hline cure & [kjuə] & [kjor] \\
\hline no & [nəv] & [nov] \\
\hline go & [gəv] & [gov] \\
\hline low & [ləo] & [lov] \\
\hline old & [ovld] & [ould] \\
\hline flow & [flov] & [flov] \\
\hline student & [stju:dənt] & [stu:dənt] \\
\hline reduce & [ridju:s] & [ridu:s] \\
\hline news & [nju:z] & [nu:z] \\
\hline
\end{tabular}

\section{Description and discussion:}

(i) There are many more differences in pronunciation than this work deals with. We chose only a few examples to demonstrate how General American (GA) and Received Pronunciation (RP) differ.

(ii) The differences between $\mathrm{AmE}$ and $\mathrm{BrE}$ are most apparent in pronunciation (Modiano, 1996).

(iii) British English uses Received Pronunciation (RP) and American English uses General American. These are just general differences. There are many differences between accents in the United States, and there are even more differences between various British accents.

(iv) RP distinguishes 7 different short pure vowel sounds - [I, e, æ, $\Lambda, \mathrm{p}, \mho$, , $]$. These can also be found in GA, except for the vowel sound [p] which is replaced by the sound [a:], e.g. not, lot, hot, knowledge, etc. In a large number of words where in RP [a:] is pronounced, in GA the front open vowel [æ] is found, e.g. dance, past, half, athlete, aunt, example, etc. In RP we often find the sound [o:] where in GA the sound [a:] occurs. The long back mid rounded [0:] loses its roundness and becomes an open [a:], e.g. thought, walk, daughter, etc.

(v) RP distinguishes eight diphthongs. Three of these end in the sound schwa - iə, eə, və, e.g. clear, dare, and cure. There are no diphthongs ending in the sound schwa in GA, rather the sound schwa is replaced by the sound [r] 
(Pavlík, 2003). Diphthong [əช] which is used in RP shifts to [ov] in GA. The mid, central vowel [ə] shifts to close mid, back, rounded vowel [o], e.g. no, go, low, old, flow, etc.

(vi) One important difference between various English accents is the pronunciation of the consonant [r]. We call American English rhotic because the ' $r$ ' is pronounced before a vowel, a consonant and at the end of a word. On the other hand RP is called non-rhotic because the consonant ' $r$ ' is not pronounced 'before a consonant and at the end of a word. It is believed that the weakening of the ' $r$ ' started in Britain in the 1600s and it took about one hundred years for the ' $r$ ' to be completely lost. The non-rhotic accent became standard among the British sometime in the 1800 s.

(vii) Rhotic accent in American English, in contrast to RP, can be found associated with the following sounds: [a:], e.g. hard; [॰:], e.g. born, and [3:], e.g. hurt, 'after the sound schwa ([ə]), e.g. later, in diphthongs ending by the sound schwa as in [iə] and [eə], e.g. here, there (Pavlík, 2003).

(viii) Pronunciation of the letter, 't', GA recognizes six different realizations of the phoneme [t].

\section{Table-4: BrE and AmE grammar differences}

\begin{tabular}{|c|c|}
\hline BrE & AmE \\
\hline They'll write a letter to them. & They'll write them. \\
\hline Raza has got the best results. & Raza has gotton the best results. \\
\hline He learnt British variety of English. & He learned English in America. \\
\hline I have got high temperature. & I have high temperature. \\
\hline Have you already eaten lunch? & Did you eat lunch already? \\
\hline Ali did not come to the college. & Ali has not come to college. \\
\hline $\begin{array}{l}\text { The teacher insisted that he should move to the other group. } \\
\text { (Subjunctive) }\end{array}$ & $\begin{array}{l}\text { The committee suggested that he be given the } \\
\text { first prize. }\end{array}$ \\
\hline Keep a water-bottle with you at all times. & Keep always a water bottle with you. \\
\hline $\begin{array}{ll}\text { (i) } & \text { The team are well prepared. } \\
\text { (ii) } & \text { The team is well prepared. }\end{array}$ & The team is well prepared. \\
\hline Have you any job?" or "Have you got any job?" & Do you have any job? \\
\hline They insist that you should teach them English. & They insist that you teach themEnglish. \\
\hline In future & In the future \\
\hline On average & On the average \\
\hline Fill in a form & Fill out a form \\
\hline In respect of & In respect to \\
\hline Their attitude towards government & Their attitude toward government \\
\hline You think that's funny, do you? (Tag question) & This is not what you said, is it? (Tag question) \\
\hline Their candidature is not valid. & Their candidacy is not valid. \\
\hline Heavy transport is problematic in cities. & Heavy transportation is problematic in cities. \\
\hline One should do one's duty. & One should do his duty. \\
\hline Who is that? & Who is this? \\
\hline This time of the year is more demanding. & This time of year is more demanding. \\
\hline He plays in a new team. & He plays on a new team. \\
\hline Please wait for half an hour. & Please wait a half hour. \\
\hline These dresses are in a sale. & These dresses are onsale. \\
\hline The minister resigned on Sunday. & The minister resigned Sunday. \\
\hline We will visit him at the weekend. & We will visit him over the weekend. \\
\hline Are your parents at home? & Are your parents home? \\
\hline Thanks for a really good meal. & Thanks for a real good meal. \\
\hline They will never agree to it. & They never will agree to it \\
\hline They visit on and off new places. & They visit off and on new places. \\
\hline They do sport throughout the year. & They play sports throughout the year. \\
\hline He agreed to it there and then. & He agreed to it then and there. \\
\hline They beat them hollow. & Team 'A' cleanedteam 'B' clocks. \\
\hline
\end{tabular}

\section{Description and Discussion:}

(i) Crystal claims, in The Cambridge Encyclopedia of the English Language, that "gotten is probably the most distinctive of all the British/American English grammatical differences" (Crystal, 1995). 
(ii) Grammatical differences between American and British English have been treated mainly by individual scholarly studies focused on particular grammatical matters. British and American differ in their morpho-syntax structures. Although many, few of the grammatical differences between British and American are great enough to produce confusion, and most are not stable because the two varieties are constantly influencing each other with borrowing both ways across the Atlantic and nowadays via the Internet.

(iii) In American English, the '-ed' form is used with some verbs that in British English are irregular, such as to learn (learned in American, learnt in British), to dream (dreamed/dreamt), to spell (spelled/spelt) etc. Other verbs, regular in British English, are used in the American variant with irregular forms. For example, verbs like, to light, to forecast, to knit, tend to receive, at past tense and present participle, the irregular forms lit, forecast, knit, instead of lighted, forecasted, and knitted.

(iv) This is not a general rule, because these irregular forms are also encountered in British English. Another peculiar aspect in American English is the use of certain forms of past participle, such as gotten, proven, shrunken, boughten, which are considered very old-fashioned, or simply not used by British speakers.

(v) In British English, collective nouns (e.g. team, police, army, audience, staff, company, government etc.) are often followed by a plural verb, while in American English, these are always followed by a singular. For instance: Manchester have won the match, is in American English: Manchester has won the match.

(vi) Use of the present perfect differs as well. When referring to an action which has begun in the past, but is going on in the present, speakers of British English use the present perfect, while Americans tend to use the past simple tense. For example: The student has already finished his work. (BrE), is in American English: The student already finished his work.

(vii) British syntax and American syntax differ for what are called 'mandative' or commanding constructions - finite clauses that occur after certain expressions of will. In standard American English, speakers are more likely to use a subjunctive form of the verb: I insist that he give you the sugar. Educated British speakers tend to prefer an expanded auxiliary: I insist that he should give you the sugar. Both forms are possible within standard American English, and the two will be understood equally well.

(viii) Firstly, the term question tag is used to designate in a general way the interrogative part of the statement. Secondly, question tag serves in some cases to refer tothe whole statement and in other cases to refer to the tag only. British and American English differ in the use of tag questions on several levels. American speakers employ tag questions with negative-positive polarity (This is not what you said, is it?) rather than British, whereas the latter use twice as much with constant positive polarity (You think that's funny, do you?). It is peculiar for an American to hear a question followed by a question tag: Have they got a new car, have they? The operator with the most frequent employment in question tags in both varieties is the verb 'be', occurring once in two instances in British and slightly less in American English. Following is the auxiliary do, again in both varieties but with major frequency in American English.

(ix) Differences in the use of nouns are differences in forms: in British English words like: candidature, centenary, cookery book, racialist, racialism, sparking plug, transport are in American English: candidacy, centennial, cook book, racist, racism, spark plug, transportation. There are also same words expressing different meanings in British and American English. Many words that originate from the UK, now possess a totally different meaning in the US. 'Bill'" is a bank note in American English, a billion is a thousand million, a newspaper man is an operator of a printing office in American English.

(x) British English and American English use different pronouns to repeat the indefinite pronoun "one". British English uses "one", for example, "One cannot succeed unless one tries hard", while American English uses "he", for example, "One cannot succeed unless he tries hard". Other examples are as follows: One should learn to take care of oneself. (BrE); One should learn to take care of himself. (AmE). One can't be too careful, can one? (BrE); One can't be too careful, can he? (AmE).

(xi) We also find different use of demonstrative pronouns between British and American English. American English tends to use 'this' in contexts where British speaker prefers 'that'. 'Who is that?' (BrE) and 'Who is this?' (AmE). Extended forms of the demonstratives are 'these ones' and 'those' ones. It appears that 'these ones' is more characteristic of British than of American English. Americans very often use 'that' to introduce restrictive clauses. Writers and speakers of British English use 'which' to introduce just about any clause they want.

(xii) Most phrases of British English have articles, while those of American English do not. British English may use 'the' in certain expressions of time where American English would have no determiner. The "the" in the standard expressions in British English "all the afternoon", "all the winter", "all the week", "this time of the year", etc. are usually omitted in American English. For example: I'll be here all afternoon. British English uses articles in front of 'disease', 'river' etc., while American English does not. For example, British English expresses in the form of 'the measles', 'the flu', 'Twin water Falls' and while American English says 'measles', , 'flu', 'Twin water Falls'. 
(xiii) In American English there are different uses of prepositions in the construction of phrases. These dresses are in a sale $(\mathrm{BrE})$. These dresses are on sale $(\mathrm{AmE})$. WhereBritish people would say "She resigned on Friday", Americans often say "She resigned Friday", but both forms are common in American usage. Similarly, "five past nine" can be expressed in American English by "five after nine" or "nine five". In front of 'weekend' and 'Christmas', British English uses 'at'or'over', while American English adopts 'over' or 'on'.

(xiv) In non-formal American English, adjectives can be used as adverbs, for example "a real good meal". However, in British English and formal American English, only adverbs can be used, "a really good meal". In American English, adverbs can be used more freely in respect of position. They can either be placed in front of auxiliary verbs or behind them, while the meaning of the sentences remains the same. For example, we can either say "They never will agree to it" or "They will never agree to it".

(xv) In British English, the adverbs "yet" and "already" cannot be used in past tense and can only be used in past perfect tense. However, in American English, they can be used both in past tense and past perfect tense. Let us see the examples: I haven't bought one yet. (BrE, AmE) I didn't buy one yet. (AmE); Have you read it already? (BrE, AmE) Did you read it already? (AmE).

(xvi) Adverbs of frequency (generally, never, usually), like those of probability, tend to occur in medial position, after the first auxiliary, if there is one. However, with these also American has a higher tolerance for placement before the first auxiliary than does British: She usually is at work from nine to five/She is usually at work from nine to five. Although British and American share a common inventory of adverbial particles, with only a few differences of form (e.g., on and off vs. off and on), they differ in their use of those particles. American English is relatively more favourable to off and on.

(xvii) A collocation is two or more words that often go together. These combinations just sound "right" to native English speakers, who use them all the time. For example, we talk about 'heavy rain'. So, 'heavy rain'is often referred to as collocations. In British English, you can "do sport". In American English you can "play sports".

\section{Conclusion}

In the light of collected data and its analysis the researcher concludes the most important aspects of the present study as follows:

(i) The history and development of British and American English as two major different dialects show that the different needs of speakers in different geographical locations influence different languages, different social and cultural conditions, all contributed to the one language dividing into two major dialects.

(ii) British English has been influenced by American English since the 17th century. Despite their continuous existence separately, America and Britain have never really lost sight of a common standard of English, because of their political link, the common literary tradition, the common reading material, and the fact that the earliest lexicographers, the early dictionary editors in the United States came from New England. American English although it has exercised a greater influence on world English than any other variety, it seems to slowly lose its status as the dominant version. The reason is that people use language not only to communicate, but also to express their social and personal identity.

(iii) The language is in a constant state of motion and unfortunately, there is no predictable direction for the changes that are taking place. Maybe American English will continue to influence other varieties of English. But it will remain a trickle, because while the British want to be able to talk intelligibly with Americans, they do not actually want to be Americans! In the contest between identity and intelligibility, identity wins.

(iv) The core of this article aimed at showing selected differences in British and American English in the areas of vocabulary, spelling, pronunciation and grammar. This study proves that the differences in these areas are many. It shows that the differences which may cause the most confusion are in the area of pronunciation and vocabulary.

(v) The English language is a dynamic system which is always changing. We can only speculate whether the two dialects will become more or less alike in the future. The fact is that in present British and American English remains one language but two very distinct dialects.

(vi) In most international exams, both varieties of English are accepted. However, while writing for an international exam (or writing in English generally) students should try to remain consistent. That means if they favour (or favor) American spelling and grammar, they should stick to that convention for the whole piece of writing.

(vii) In a word, the conclusion of conclusion is that the influence of American English on British English was much greater in the beginning, but nowadays words and phrases are filtered and everything useless, pompous, or simply fashion is to be eliminated. British English will probably continue to be influenced by American English, 
especially as long as this influence is manifest in fields of activity where the lack of appropriate words and phrases demands it.

\section{Recommendation}

In the light of conclusion of the present study, it is suggested that the teacher, the taught and other users of English language either it is British and American need to be familiar with the variations in the sub-fields of linguistics specifically with reference to $\mathrm{BrE}$ and $\mathrm{AmE}$ to develop confidence and perform in a better way. Moreover, further in depth study in every sub-area like phonetics, phonology, spelling system, morphology, phrases, idioms loaded with cultural aspects and syntactic rules, is recommended for some sort of useful addition to the existing research.

\section{Acknowledgement}

This is to acknowledge the support that the researcher got through the remarkable research work done by the learned scholars mentioned in the references, in the accomplishment of this article. The researcher once again appreciates the marvelous research work that they contributed to the existing research. Finally, thanks also go to the library staff of Jazan University, Jazan (Kingdom of Saudi Arabia).

\section{References}

Algeo, John. (1986), “The Two Streams: British and American English,” Journal of English Linguistics Vol. 19, No. 2 (Oct 1986), 269-84.

Algeo J. 2001. (edited) The Cambridge History of the English Language volume IV - English in North America, Cambridge University Press, 2001, Cambridge. p. 338.

American Heritage Dictionary, 1969. [Online] Available: http://ahdictionary.com/, March 16, 2012.

Crytal, D. 1995. The Cambridge Encyclopedia of the English Language. Cambridge UnivDavies, Ch. (2005)Divided by a Common Language. Mayflower Press. ISBN-13 978-0-618-00275-7

Finegan E. and Rickford R. J. Language in the USA - Themes for the Twenty-first Century, Cambridge University Press, 2004, New York. pp. 15-16

Gelderen, Van. E. 2006. A History of the English Language. Amsterdam/Philadelphia: John Benjamins Publishing Company. ISBN 902723236

Kachru, B, Braj.et.al. (2006).The Handbook of World Englishes. ISBN:9781405111850Online ISBN:9780470757598 |DOI:10.1002/9780470757598

Katerina,Pauliuc. The Influence of American English on British EnglishAnnoAccademico 2013/2014

Markward, Albert, 1958. A Communicative Grammar of English. Singapore: Longman.

Modiano, Marko. (1996). A Mid-Atlantic Handbook : American and British English. Sweden: Student literature

Mulkeen, Declan. 2016. How to Confuse a Foreigner : American Vs British English. https://www.communicaid.com/business-language-courses/blog/uk-usa-two-countries-divided-commonlanguage/

Nancy, Salama. 1976. Teaching Foreign Language Skill. Chicago: The University of Chicago Press.

Pavlik, R. 2003. A Theoretical Introduction to English Phonetics and Phonology. Bratislava: RETAAS s.r.o. ISBN 8089113-08-7.https://sites.google.com/site/radoslavpavlik44/my-publications-4

Pavlik, R. (2006). Elements of Sociolinguistics. Bratislava, UniverzitaKomenského, 279 s. ISBN: 80-223-2112-5. https://sites.google.com/site/radoslavpavlik44/my-publications-4

Sitzman,Ryan.(2019)https://www.fluentu.com/blog/english/differences-between-american-and-britishnglish/Triyadi,Deris.https://www.academia.edu/5674243/The_Importance_of_Knowing_The_Differences_Bet ween_British_and_American_English) DerisTriyadi,The Reader's Digest', http://www.rd.com/ April 10, 2019.

Weinreich, Uriel. (1953). Languages in contact: Findings and problems. New York:Linguistic Circle of New York.

Wilde, Oscar. (1887) http://www.oscarwildeinamerica.org/quotations/common-language.html

Yazawa, Melvin. (2004). Noah Webster: Oxford Dictionary of National Biographyhttps://doi.org/10.1093/ref:odnb/68670; Published in print: 23 September 2004; Published online: 23 ... 